\title{
PENGARUH BIAYA PROMOSI TERHADAP PENINGKATAN PENJUALAN PADA PT. AMARTA HONDA MOTOR
}

\author{
Dicky Maulana Zulkarnaen \\ Universitas Mitra Karya \\ dickymaulana@umika.ac.id
}

\begin{abstract}
Abstrak
Promosi bisa disebut sebagai bagian penting dari aspek pemasaran. Promosi sendiri merupakan upaya dari perusahaan untuk mengkomunikasikan produknya kepada masyarakat luas dengan tujuan menstimulus masyarakat untuk melakukan pembelian. Dalam melakukan promosi, tentunya akan ada biaya yang dikeluarkan perusahaan. Biaya Promosi di PT Amarta Honda Motor adalah setiap nilai yang dikorbankan oleh perusahaan untuk kepentingan promosi dalam kaitannya tentang pemasaran produk perusahaan tersebut.

Penelitian ini dimaksudkan untuk melihat sejauh mana biaya promosi yang dilakukan perusahaan PT Amarta Honda Motor mempengaruhi peningkatan volume penjualan atas produk sepeda motor Honda. Mengetahui sejauh mana pengaruh biaya promosi terhadap peningkatan volume penjualan produk pada PT. Amarta Mitra Sejati. Selain itu juga menganalisis hubungan dan pengaruh biaya promosi terhadap peningkatan volume penjualan produk pada PT. Amarta Mitra Sejati

Untuk mengaplikasikan tujuan tersebut maka digunakan metode deskriptif, metode analisis regresi linear sederhana, analisis koefisien korelasi dan pembuktian hipotesis dengan uji t. Pengaruh biaya promosi terhadap penjualan sepeda motor pada PT Amarta Mitra Sejati sangat erat. Dapat diketahui dari analisis korelasi antara biaya promosi yang dilakukan dengan hasil penjualan menunjukkan angka sebesar 0,899 sedangkan berdasarkan analisis koefisien determinasi sebesar 80,8 \% setiap peningkatan biaya promosi diikuti dengan peningkatan penjualan .

Pengujian hipotesis menggunakan $t$ hitung sebesar 3,551 dan $t$ tabel 2,353 dengan nilai signifikasi 0,038<0,05, maka Ho ditolak dan Ha diterima, yang berarti ada pengaruh yang signifikan dari biaya promosi terhadap penjualan.
\end{abstract}

Kata kunci : Kualitas pelayanan, Harga, Keputusan Pembelian

\section{PENDAHULUAN}

Perkembangan perekonomian pada era globalisasi sekarang ini sangat pesat dan ketat. Untuk itu setiap perusahaan dituntut untuk melakukan perubahan dalam segala bidang, salah satunya adalah bidang pemasaran. Semakin tingginya tingkat persaingan di bisnis lokal maupun global dan kondisi ketidakpastian memaksa perusahaan untuk mencapai keunggulan kompetitif agar mampu memenangkan persaingan di dunia bisnis.

Setiap perusahaan yang berorientasi mencari laba harus dapat mengelola perusahaan tersebut dengan se-efektif dan se-efisien mungkin sehingga dapat meminimalkan kemungkinan terjadinya kerugian dan memaksimalkan keuntungan yang dapat menunjang kemajuan dari kehidupan usaha tersebut. 
Bagian pemasaran merupakan bidang yang harus diperhatikan demi keberhasilan perusahaan di samping kegiatan bidang lainnya seperti produksi, personalia dan keuangan. Karena pemasaran merupakan ujung tombak perusahaan yang diharapkan mampu mendistribusikan produknya dengan se-efektif dan se- efisien mungkin, sehingga mampu merealisasikan tujuan perusahaan baik untuk jangka pendek dan jangka panjang. Selain itu pemasaran juga merupakan faktor terpenting yang turut mempengaruhi kemajuan suatu perusahaan dalam meningkatkan volume penjualan dimana bertujuan memberikan kepuasan terhadap keinginan dan kebutuhan konsumen.

Salah satu kegiatan yang terpenting dalam manajemen pemasaran yakni dengan melakukan promosi, karena promosi merupakan kegiatan perusahaan dalam usahanya untuk berkomunikasi dengan konsumen. Strategi dan penerapan promosi yang tepat merupakan salah satu cara untuk mengkomunikasikan produk kepada konsumen. Pemilihan bentuk promosi setiap perusahaan sangat berbeda- beda tergantung pada karakteristik produk dan kebijakan pemasaran yang dilaksanakan.
Promosi memerlukan lebih daripada sekedar memperkenalkan keunggulan- keunggulan produk, dan harga yang menarik, serta membuatnya dapat terjangkau, akan tetapi kegiatan promosi dimaksudkan untuk dapat melakukan komunikasi dengan konsumen, memperkenalkan, membujuk, mempengaruhi dan mendorong konsumen untuk membeli produk yang ditawarkan serta dapat juga digunakan untuk membangun citra perusahaan di mata konsumen. Perusahaan-perusahaan juga harus berkomunikasi dengan pihak-pihak yang berkepentingan sekarang dan yang akan datang, serta masyarakat umum. Penggunaan media televisi maupun media promosi lainnya sama-sama penting. Pandangan baru tentang komunikasi pemasaran dewasa ini adalah sebagai dialog interaktif antara perusahaan dengan pelanggannya yang berlangsung selama pra-penjualan, penjualan, pemakaian dan pasca pemakaian.

Perusahaan-perusahaan saat ini juga telah menyadari bahwa mereka harus mengubah cara-cara mereka memasarkan dan mempromosikan produk maupun jasanya. Perusahaan tidak dapat hanya terpaku pada satu 
instrumen komunikasi pemasaran saja, mereka harus mengkombinasikan berbagai cara yang ada untuk mengkomunikasikan produknya.

Untuk itu, perusahaanperusahaan harus mengalokasikan anggaran promosi ke dalam biaya promosi se-efisien mungkin untuk mendapatkan nilai penjualan yang maksimal. Bagi perusahaan, sangatlah penting untuk mengatur seberapa besar biaya yang diperlukan untuk memperkenalkan produknya dan juga tindakan persuasi agar masyarakat tertarik dengan produk tersebut. Alokasi biaya ini dirasa penting karena akan mempengaruhi seberapa besar masyarakat yang mengetahui produk yang ada dan seberapa besar pengaruh promosi tersebut terhadap minat masyarakat untuk membelinya. Biaya promosi dikeluarkan oleh perusahaan antara lain untuk membuat pameran produk, memberi sponsor dan membuat iklan di media cetak maupun media elektronik. Sudah pasti perusahaan ingin selalu meningkatkan jumlah penjualan untuk mendapatkan laba yang lebih besar, dan dapat dilihat betapa besar peranan promosi dalam upaya untuk mencapai tujuan perusahaan yaitu meningkatkan volume penjualan.
Persaingan yang tinggi membuat orang-orang di dunia usaha terus berupaya untuk mendapatkan peluangpeluang pasar. Tidak terkecuali di bidang usaha otomotif. Usaha otomotif terutama kendaraan roda dua saat ini memang besar pangsa pasarnya namun juga banyak pesaingnya. Hampir di setiap sudut jalan dapat kita temukan berbagai dealer sepeda motor dengan berbagai merek yang dijualnya. Mulai dari dealer resmi hingga dealer-dealer kecil lainnya. PT Amarta Mitra Sejati merupakan salah satu usaha berbadan hukum yang menggeluti dunia usaha ini. Untuk bisa bertahan di usaha ini, tentunya perusahaan melakukan upayaupaya pemasaran agar produknya bisa laku di pasaran. Upaya-upaya itu salah satunya adalah dengan melakukan kegiatan promosi.

Tujuan penelitian ini, mengetahui sejauh mana pengaruh biaya promosi terhadap peningkatan volume penjualan produk pada PT. Amarta Mitra Sejati, menganalisis hubungan dan pengaruh biaya promosi terhadap peningkatan volume penjualan produk pada PT. Amarta Mitra Sejati. 


\section{METODOLOGI PENELITIAN}

Penelitian ini juga merupakan Case and Field Study Research atau penelitian studi kasus. Studi kasus merupakan penyelidikan yang mendalam pada suatu unit sosial yang menghasilkan suatu gambaran lengkap, dan terorganisir dengan baik mengenai unit tersebut. Tergantung pada tujuan, lingkup studi ini dapat mencakup keseluruhan siklus hidup atau hanya bagian-bagian tertentu, studi ini dapat hanya terfokus pada faktor-faktor yang spesifik saja atau dapat juga mengambil keseluruhan dari unsur dan peristiwa. Metode penelitian yang digunakan dalam pelaksanaan penelitian ini adalah dengan metode eksplanatori, yaitu metode penelitian suatu penelitian yang menjelaskan kedudukan variabel variabel yang diteliti serta hubungan antara satu variabel dengan variabel yang lain.

\subsection{Jenis Data}

Jenis data berdasar sumber yang digunakan oleh penulis adalah:

2.1.1. Jenis data berdasarkan sumber yang digunakan penulis adalah:

a. Data Primer merupakan data-data yang dikumpulkan dan diperoleh secara langsung dari objek penelitian perusahaan. b. Data Sekunder adalah data yang diperoleh secara tidak langsung berupa dokumen-dokumen dan laporan tertulis serta informasi lain yang ada hubungannya dengan masalah ini. Dalam hal ini penulis mengumpulkan data secara library research, yaitu dengan jalan

melihat buku-buku (literatur) yang berhubungan dengan masalah penelitian dan dapat melengkapi atau mendukung data primer.

2.1.2. Jenis data berdasarkan bentuk yang digunakan penulis dalam penelitian ini yaitu:

a. Data kuantitatif adalah data biaya promosi yang dikeluarkan oleh perusahaan PT. Amarta Mitra Sejati dan pendapatan penjualan produk PT. Amarta Mitra Sejati

b. Data kualitatif yaitu data atau informasi dalam bentuk tertulis mengenai keadaan perusahaan dan bentuk kegiatan perusahaan PT. Amarta Mitra Sejati

\subsection{Variabel Penelitian}

Variabel penelitian adalah objek penelitian, atau apa yang menjadi fokus di dalam suatu penelitian. Dalam penelitian kali ini, varibel penelitian digolongkan menjadi dua variabel yaitu variabel bebas dan variabel terikat. 


\subsubsection{Variabel bebas atau biasa disebut} variabel independen adalah variabel yang dimanipulasi untuk mengamati efeknya terhadap variabel terikat. Pada penelitian ini, yang menjadi variabel bebas atau dependent (X) adalah biaya promosi. Dalam hal ini merupakan biaya yang dikeluarkan untuk kegiatankegiatan yang dilakukan perusahaan PT. Amarta Mitra Sejati guna mendorong konsumen membeli produk dan jasa yang ditawarkan dengan berbagai jenis promosi yang dilakukan.

3.2.2. Variabel terikat atau biasa disebut variabel dependent merupakan variabel yang nilainya dipengaruhi oleh variabel bebas. Pada penelitian ini yang berperan sebagai variabel terikat $(\mathrm{Y})$ adalah volume penjualan. Volume penjualan yang dimaksudkan adalah total penjualan yang dinilai dengan unit oleh perusahaan dalam periode tertentu untuk mencapai laba yang maksimal sehingga dapat menunjang pertumbuhan perusahaan.

\subsection{Teknik Pengumpulan Data}

Dalam penulisan ini, teknik pengumpulan data yang penulis tempuh adalah sebagai berikut:

$$
\begin{aligned}
& \text { 2.3.1. Riset Kepustakaan yaitu } \\
& \text { penelitian yang dilakukan dengan } \\
& \text { cara mempelajari buku-buku yang }
\end{aligned}
$$

berhubungan dengan masalah yang dihadapi untuk mendukung analisis data yang diperlukan untuk karya tulis ini.

2.3.2. Observasi yaitu metode penelitian dengan melakukan pengamatan secara langsung pada objek penelitian untuk mendapatkan data-data yang dibutuhkan dalam penyusunan skripsi.

2.3.3. Wawancara. Penulis melakukan tanya jawab dengan pihak PT Amarta Mitra Sejati untuk mendapat informasi mengenai data-data yang dibutuhkan.

2.3.4. Dokumentasi. Penelitian ini dilakukan dengan cara memperoleh laporan dan dokumen-dokumen lainnya yang erat hubungannya dengan objek penelitian dan membaca literaturliteratur sebagai dasar teori yang akan dijadikan sebagai landasan teoritis dalam penulisan skripsi.

\subsection{Teknik Analisis Data}

Metode analisis yang digunakan dalam memecahkan masalah yang telah dikemukakan serta untuk membuktikan hipotesis adalah:

2.4.1. Analisis deskriptif yakni suatu analisis yang menguraikan perkembangan penjualan yang dicapai oleh perusahaan.

2.4.2. Regresi merupakan suatu alat ukur yang juga dapat digunakan untuk 
mengukur ada atau tidaknya korelasi antarvariabel. Jika kita memiliki dua buah variabel atau lebih maka sudah selayaknya apabila kita ingin mempelajari bagaimana variabelvariabel itu berhubungan atau dapat diramalkan.

Analisis regresi berguna untuk mendaptkan hubungan fungsional antara dua variabel atau lebih. Selain itu analisis regersi berguna untuk mendapatkan pengaruh antar variabel prediktor terhadap variabel kriteriumnya atau meramalkan pengaruh variabel prediktor terhadap variabel kriteriumnya (Analisis regresi mempelajari hubungan yang diperoleh dinyatakan dalam persamaan matematika yang menyatakan hubungan fungsional antara variabel-variabel. Hubungan fungsional antara satu variabel prediktor dengan satu variabel kriterium disebut analisis regresi sederhana (tunggal), sedangkan hubungan fungsional yang lebih dari satu variabel disebut analisis regresi ganda. Analisis regresi linear yakni suatu analisis untuk melihat sejauh mana pengaruh biaya promosi terhadap peningkatan penjualan produk, dengan menggunakan rumus regresi yaitu :

$\mathrm{Y}=\mathrm{a}+\mathrm{bX}$

Di mana:
$\mathrm{Y}=$ Penjualan

$\mathrm{X}=$ Biaya Promosi

$\mathrm{a}=$ Nilai konstanta (Nilai $\mathrm{Y}$ apabila $\mathrm{X}=0$ )

$\mathrm{b}=$ besarnya perubahan $\mathrm{Y}$ bila $\mathrm{X}$ bertambah 1 unit

Koefisien korelasi adalah suatu nilai untuk mengukur kuatnya hubungan linier antara dua variabel yaitu variabel bebas $(\mathrm{x})$ dan variabel terikat (y). Koefisien korelasi biasanya dilambangkan dengan huruf r. Nilai koefisien korelasi (r) berkisar antara -1 sampai dengan +1 . Jika nilai $r$ mendekati +1 atau -1, maka $\mathrm{x}$ dan $\mathrm{y}$ memiliki korelasi linier yang tinggi. Jika nilai $\mathrm{r}=+1$ atau $\mathrm{r}=-1$ maka $\mathrm{x}$ dan $\mathrm{y}$ memiliki korelasi linier sempurna. Jika nilai $r=0$ maka $\mathrm{x}$ dan y tidak memiliki relasi (hubungan) linier (dalam kasus $r$ mendekati 0 , dapat dilanjutkan ke regresi eksponensial). Lebih jelasnya, berikut tabel rentang koefisien korelasi. Tanda positif (+) dan dan negatif (-) memberikan informasi mengenai arah hubungan antara dua variabel tersebut. Jika bernilai positif maka kedua variabel memiliki hubungan yang searah. Dalam arti lain peningkatan variabel bebas (x) akan bersamaan dengan peningkatan variabel terikat (y) dan demikian pula sebaliknya. Jika bernilai negatif artinya korelasi antara dua variabel tersebut 
bersifat berlawanan. Peningkatan nilai variabel bebas (x) akan dibarengi dengan penurunan nilai variabel terikat (y).

\section{Analisis Koefisien Determinasi}

Koefisien determinasi adalah analisis yang digunakan untuk mengetahui kekuatan pengaruh biaya promosi terhadap tingkat penjualan. Rumus untuk menghitung koefisien determinasi adalah dengan cara mengkuadratkan koefisien korelasi yang telah ditemukan.

$R=r 2 \times 100 \%$

Kriteria untuk analisis koefisien determinasi:

a. Jika $\mathrm{R}$ mendekati nol (0), ini berarti pengaruh variabel bebas terhadap variabel terikat, lemah.

b. Jika $\mathrm{R}$ mendekati satu, ini berarti pengaruh variabel bebas terhadap variabel terikat, kuat.

Pengujian Hipotesis

Pengujian hipotesis yang diajukan dalam penelitian ini adalah uji pihak kanan yang berarti "Terdapat pengaruh positif biaya promosi terhadap peningkatan penjualan."

Jika Ho $=\mu \leq \mathrm{a}$ atau $\mu=0$ tidak terdapat hubungan positif biaya promosi terhadap peningkatan penjualan.
Jika $\mathrm{Ha}=\mu>$ a terdapat hubungan positif biaya promosi terhadap peningkatan penjualan.

Kriteria:

Ho diterima bila $\mathrm{t}$ hitung $\leq \mathrm{t}$ tabel

Ho ditolak bila $\mathrm{t}$ hitung $>\mathrm{t}$ tabel

2.5 Tempat dan Waktu Penelitian.

\section{Tempat Penelitian}

Penelitian ini di lakukan langsung di tempatnya langsung yaitu di Jl. Sultan Hasanudin No.255 Tambun Bekasi, Jawa Barat.

\section{Waktu Penelitian}

Waktu penelitian ini di laksanakan mulai bulan Oktober 2019 sampai Desember 2019.

\section{HASIL DAN PEMBAHASAN}

PT Amarta Honda Motor menggunakan lebih dari satu bentuk promosi dalam aktivitas promosinya. Kegiatan promosi yang dilakukan oleh PT Amarta Honda Motor dalam upaya meningkatkan penjualan sepeda motor dengan periklanan, personnal selling, dan sales promotion.

Secara lebih rinci aktivitas promosi yang dilakukan adalah sebagai berikut

1. Periklanan (Advertising)

2. Sales promotion

3. Personal Selling

4. Hubungan Masyarakat 
Berikut ini data biaya promosi dan penjualan PT Amarta Honda Motor

Tabel Biaya Promosi dan Penjualan PT Amarta

\begin{tabular}{|l|l|l|}
\hline Tahun & $\begin{array}{l}\text { Biaya } \\
\text { Promosi }\end{array}$ & $\begin{array}{l}\text { Penjualan } \\
\text { (unit) }\end{array}$ \\
\hline 2015 & 15.300 .000 & 503 \\
\hline 2016 & 17.550 .000 & 536 \\
\hline 2017 & 16.150 .000 & 497 \\
\hline 2018 & 17.400 .000 & 514 \\
\hline 2019 & 18.950 .000 & 548 \\
\hline
\end{tabular}

Perkembangan Biaya Promosi PT Amarta;

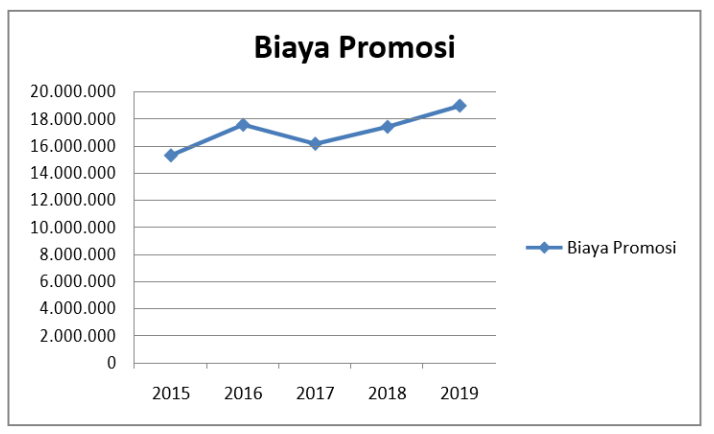

Gambar Grafik Perkembangan Biaya Promosi

Berdasar data diatas maka penulis memberikan penjelasan sebagai berikut:

a. Pada tahun 2015 total biaya promosi yang dikeluarkan oleh PT Amarta adalah sebesar Rp 15.300.000,00.

b. Pada tahun 2016 total biaya promosi yang dikeluarkan oleh PT Amarta Mitra Sejati adalah sebesar Rp17.550.000,00. Jika dibandingkan dengan tahun sebelumnya berarti mengalami kenaikan sebesar Rp 2.250.000,00 atau $14,71 \%$.

c. Pada tahun 2017 total biaya promosi yang dikeluarkan PT Amarta Mitra Sejati sebesar Rp 16.150.000,00. Hal ini menunjukkan penurunan sebesar $\mathrm{Rp}$ 1.400.000,00 dibanding tahun 2016 dengan persentase penurunan $7,98 \%$.

d. Pada tahun 2018 total biaya promosi yang dikeluarkan adalah sebesar Rp 17.400.000,00 dan ini menunjukkan kenaikan dari tahun sebelumnya dengan persentase sebesar 7,74\% dengan angka Rp 1.250.000,00.

e. Pada tahun 2019 total biaya promosi yang dikeluarkan adalah Rp 18.950.000,00. Hal ini menunjukkan kenaikan sebesar $\operatorname{Rp} 1.550 .000,00$ dari tahun sebelumnya dengan persentase kenaikan $8,91 \%$.

Perkembangan Tingkat Penjualan PT.

Amarta

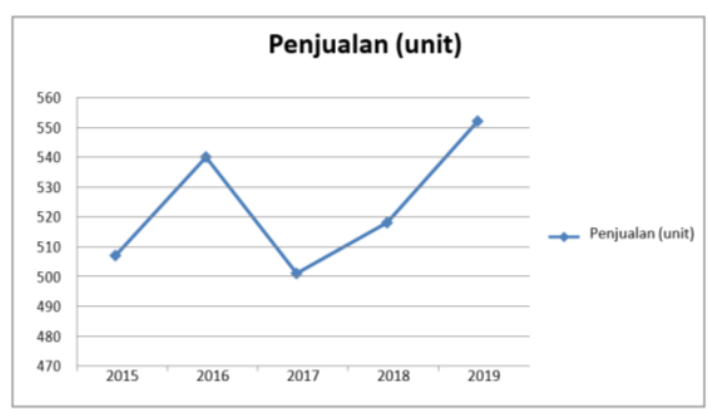

Gambar Grafik Perkembangan Penjualan 
a. Pada tahun 2015 total penjualan sepeda motor Honda yang dilakukan oleh PT Amarta Mitra Sejati adalah sebesar 503 unit

b. Pada tahun 2016 total penjualan yang dilakukan oleh PT Amarta Mitra Sejati adalah sebesar 536 unit. Jika dibandingkan dengan tahun sebelumnya berarti mengalami kenaikan sejumlah 33 unit atau sebesar $6,56 \%$.

c. Pada tahun 2017 total penjualan yang dilakukan PT Amarta Mitra Sejati sebesar 497 unit. Hal ini menunjukkan penurunan sebesar 39 unit dibanding tahun 2016 dengan persentase penurunan $7,28 \%$.

d. Pada tahun 2018 total penjualan yang dilakukan adalah sebesar 514 unit dan ini menunjukkan kenaikan dari tahun sebelumnya dengan persentase sebesar 3,42\% dengan angka kenaikan 17 unit.

e. Pada tahun 2019 total penjualan yang dikeluarkan adalah 548 unit.

Hal ini menunjukkan kenaikan sebesar 34 unit dari tahun sebelumnya dengan persentase kenaikan $6,61 \%$

Dari data tabel 4.2 serta gambar 4.2 dan 4.3 grafik tersebut dapat kita lihat biaya promosi yang $\mathrm{d}$ igunakan dan penjualan PT Amarta Mitra Sejati tidak mengalami perubahan/ fluktuasi yang terlalu signifikan dengan kisaran biaya promosi di angka belasan juta. Demikian halnya penjualan yang berkisar lima ratusan unit per tahunnya Perbandingan Grafik Biaya Promosi dan Penjualan

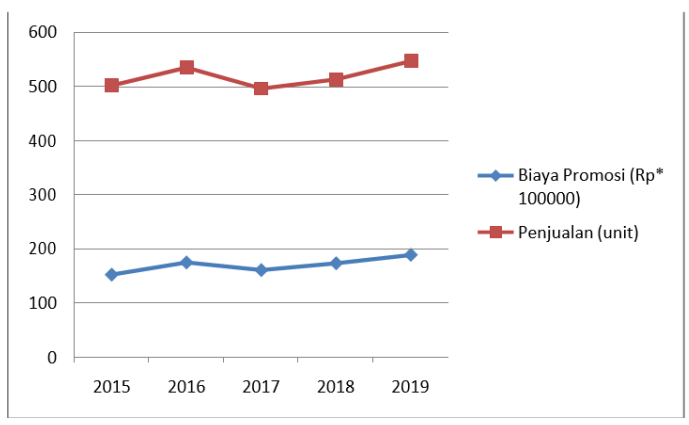

\section{Gambar Perbandingan Garfik Biaya Promosi dan Penjualan}

Dari gambar grafik di atas dapat kita lihat bahwa grafik garis biaya promosi mirip pergerakannya atau berbanding positif dengan grafik garis penjualan.

Berdasarkan data tabel 4.2, dengan menggunakan SPSS versi 21 didapatkan hasil sebagai berikut:

\section{Regression}

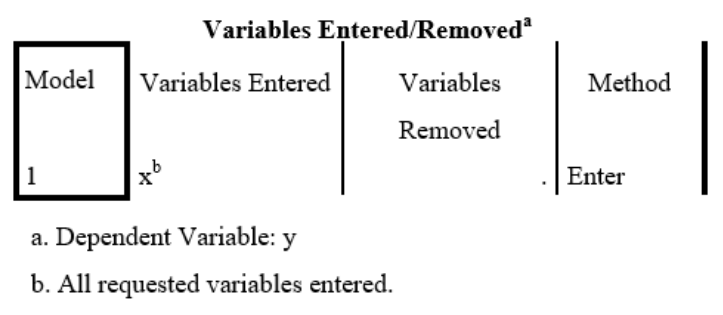

Tabel diatas menjelaskan tentang variabel yang dimasukkan atau dibuang dan metode yang digunakan. Dalam hal ini variabel yang dimasukkan adalah 
variabel nilai x yang dalam penelitian ini adalah biaya promosi.

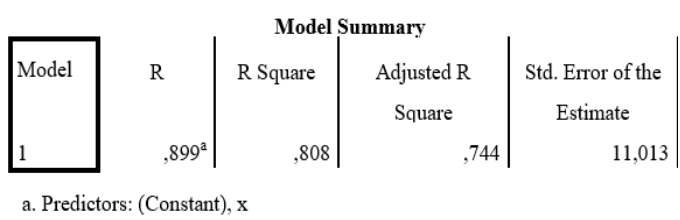

Tabel diatas menjelaskan besarnya nilai hubungan/korelasi (r) yaitu sebesar 0,899 dan dijelaskan besarnya persentase pengaruh variabel bebas (biaya promosi) terhadap variabel terikat (penjualan) yang disebut koefisien determinasi yang merupakan penguadratan dari korelasi (r). Dari output tersebut diperoleh koefisien determinasi (r2) sebesar 0,808, yang mengandung pengertian bahwa pengaruh variabel bebas (biaya promosi) terhadap variabel terikat (penjualan) adalah $80,8 \%$. Ini menunjukkan bahwa R2 mendekati 1. Hal ini berarti pengaruh variabel bebas terhadap variabel terikat bersifat kuat. Dan terdapat faktor-faktor lain yang mempengaruhi penjualan PT Amarta Honda Motor sebesar 19,2\%.

\begin{tabular}{|ll|r|r|r|r|r|}
\hline Model & & Sum of Squares & df & Mean Square & F & Sig. \\
& Regression & 1529,348 & 1 & 1529,348 & 12,610 &, $038^{b}$ \\
1 & Residual & 363,852 & 3 & 121,284 & & \\
& Total & 1893,200 & 4 & & &
\end{tabular} a. Dependent Variable: $y$

Pada bagian ini menjelaskan apakah ada pengaruh nyata (signifikan) variabel biaya promosi $(\mathrm{x})$ terhadap variabel penjualan (y). Dari output tersebut terlihat bahwa $\mathrm{F}$ hitung $=12,610$ dengan tingkat signifikasi/probabilitas $0,038<0,05$, maka model regresi dapat dipakai untuk memprediksi variabel penjualan (y).



Berdasarkan tabel hasil analisis regresi linier mengenai harga promosi yang berpengaruh terhadap volume penjualan, maka didapat persamaan regresi sebagai berikut:

Pada tabel coefficients, di kolom B constant (a) adalah 281,385, sedangkan nilai biaya promosi (x) adalah 0,00001396

$\mathrm{Y}=\mathrm{a}+\mathrm{bX}$

$\mathrm{Y}=281,385+0,00001396 \mathrm{X}$

Penjualan $=281,385+0,00001396$ Biaya

Promosi

Dimana:

$\mathrm{a}=364,792$ merupakan nilai konstan, dengan kata lain jika biaya promosi sama dengan nol maka penjualan sebesar 381 unit (dibulatkan).

$\mathrm{b}=0,350$ merupakan koefisien regresi $\mathrm{X}$ artinya apabila biaya promosi (x) dinaikkan sebesar Rp 100.000,00 maka penjualan akan meningkat sebesar 1 unit (pembulatan dari 1,396) 
Selain menggambarkan persamaan regresi, tabel output diatas juga menampilkan uji signifikasi dengan uji $\mathrm{t}$ untuk mengetahui apakah ada pengaruh yang nyata (signifikan) antara variabel x (biaya promosi) terhadap variabel y (penjualan).

Hipotesis:

$\mathrm{Ho}=$ tidak ada pengaruh yang nyata (signifikan) dari variabel $\mathrm{x}$ (biaya promosi) terhadap variabel y (penjualan) $\mathrm{H} 1=$ Ada pengaruh yang nyata (signifikan) dari variabel $\mathrm{x}$ (biaya promosi) terhadap variabel y (penjualan) Dari output di atas dapat diketahui nilai $\mathrm{t}$ hitung $=3,551$ dan $t$ tabel $=2,353$ dengan nilai signifikasi $0,038<0,05$, maka Ho ditolak dan $\mathrm{Ha}$ diterima, yang berarti ada pengaruh yang signifikan dari biaya promosi terhadap penjualan.

\section{KESIMPULAN}

Berdasarkan uraian dan penjelasan tersebut, dapat diketahui bahwa PT Amarta Mitra Sejati melakukan bauran promosi dengan advertising, sales promotion, public relation dan personal selling.

Jika dibandingkan dari tahun 2015 total biaya promosi yang dikeluarkan oleh PT Amarta pada tahun 2016 mengalami kenaikan sebesar Rp
2.250.000,00 atau $14,71 \%$. Total penjualan yang dilakukan oleh PT Amarta Mitra Sejati mengalami kenaikan sejumlah 33 unit atau sebesar $6,56 \%$.

Perbandingan biaya promosi tahun 2016 ke 2017 menunjukkan penurunan sebesar $\mathrm{Rp} 1.400 .000,00$ persentase penurunan $7,98 \%$. Penjualan mengalami penurunan pula sebesar 39 unit dibanding tahun 2016 dengan persentase penurunan $7,28 \%$.

Pada tahun 2018 total biaya promosi yang dikeluarkan menunjukkan kenaikan dari tahun sebelumnya dengan persentase sebesar 7,74\% dengan angka Rp 1.250.000,00. Total penjualan yang dilakukan menunjukkan kenaikan dari tahun sebelumnya dengan persentase sebesar 3,42\% dengan angka kenaikan 17 unit.

Pada tahun 2019 total biaya promosi menunjukkan kenaikan sebesar Rp1.550.000,00 dari tahun sebelumnya dengan persentase kenaikan $8,91 \%$. Total penjualan menunjukkan kenaikan sebesar 34 unit dari tahun sebelumnya dengan persentase kenaikan $6,61 \%$

Pengaruh biaya promosi terhadap penjualan sepeda motor pada PT Amarta Mitra Sejati sangat erat. Dapat diketahui dari analisis korelasi 
antara biaya promosi yang dilakukan dengan hasil penjualan menunjukkan angka sebesar

0,899 sedangkan berdasarkan analisis koefisien determinasi sebesar 80,8\% setiap peningkatan biaya promosi diikuti dengan peningkatan penjualan .

Pengujian hipotesis menggunakan thitung sebesar 3,551 dan $\mathrm{t}$ tabel 2,353 dengan nilai signifikasi 0,038<0,05, maka Ho ditolak dan $\mathrm{Ha}$ diterima, yang berarti ada pengaruh yang signifikan dari biaya promosi terhadap penjualan.

\section{Saran}

Ada baiknya juga perusahaan memperhatikan faktor-faktor lain yang mungkin berpengaruh terhadap tingkat penjualan agar mendapatkan laba yang maksimal dari penjualan.

\section{DAFTAR PUSTAKA}

Aaker, David. 2019. Manajemen Pemasaran Strategis Ed.8. Jakarta: Salemba Empat.

Abdullah, Thamrin; Tanti, Francis. 2014. Manajemen Pemasaran. Jakarta: Raja

Kotler, Amstrong. 2013. Prinsipprinsip Pemasaran, Edisi ke12. Penerbit Erlangga.
Kotler, Philip and Kevin Lane Keller, 2012. Marketing Management, Edisi 14, New Jersey: PrenticeHall Published.

Hawkin dan Lonney dikutip dalam Tjiptono, 2010. Indikator Keputusan Pembelian, Jakarta: Binarupa Aksara

Fandy Tjiptono. 2014. Atribut Kepuasan Konsumen (Prinsip, Penerapan, Penelitian). Yogyakarta. Andi.

Kotler dan keller 2009. Manajemen Pemasaran, jilid 1, edisi ke 13 Jakarta. Penerbit Erlangga

Assauri, 2012. Manajemen Pemasaran, Jakarta : PT Raja Grafindo. 